Портянко Т. В., аспірант *

Полтавська державна аграрна академія

\title{
РОЛЬ МІКРОФЛОРИ У ВИНИКНЕННІ ЗАПАЛЬНИХ ЗАХВОРЮВАНЬ ПАРОДОНТУ В КОТІВ
}

\section{Рецензент - доктор ветеринарних наук, професор В. П. Бердник}

\begin{abstract}
Наведено літературні дані про вплив мікроорганізмів зубної бляшки на розвиток хвороб пародонту. Визначено видовий склад мікрофлори ротової порожнини при запальних захворюваннях пародонту в домашніх котів і порівняно з клінічно здоровими тваринами. Встановлено, щзо при гінгівітах переважає кокова мікрофлора, зокрема золотистий стафілокок, при пародонтитах збільшується частка ентеробактерій. Досліджена чутливість виділених мікроорганізмів до антибіотиків і даються рекомендації до їх застосування.
\end{abstract}

Ключові слова: мікрофлора, пародонт, пародонтит, гінгівіт, коти.

Постановка проблеми. Захворювання пародонту складають найбільшу групу хвороб ротової порожнини в котів. Вони є однією з головних причин втрати зубів, виникнення деформацій, зниження функціональних можливостей зубощелепової системи, формування хронічних вогнищ поза ротовою порожниною, сенсибілізації організму і розвитку різних форм соматичної патології. За даними австралійських учених, захворювання пародонту реєструються у 53-95\% старих собак і у 25-50 \% старих кішок [2].

Незважаючи на те, що ротова порожнина $\epsilon$ збалансованою біологічною системою, завжди існує загроза ураження тканин пародонту з боку мікрофлори зубних нашарувань, зубної бляшки та твердих зубних відкладень. На сьогодні встановлено, що пусковим механізмом запального процесу в навколозубних тканинах $є$ порушення співвідношення різних асоціацій мікроорганізмів, баланс яких суттєво залежить від гігієнічного стану ротової порожнини, зокрема від наявності зубного каменю $[1,6]$.

Аналіз основних досліджень i публікацій, у яких започатковано розв'язання проблеми. Аналіз літературних даних свідчить про те, що патологічні процеси, локалізовані в ротовій порожнині (стоматит, гінгівіт, пародонтит та захворювання зубів різного ступеня складності), реєструються у собак і кішок, відповідно, у 23 та
$17 \%$ випадків від загальної кількості дрібних домашніх тварин, власники яких звертаються до лікаря ветеринарної медицини 3 приводу захворювань незаразної етіології [2].

Важливе місце 3-поміж патології органів ротової порожнини займають хвороби пародонту. Зазвичай, вони супроводжуються складними й глибокими порушеннями на морфологічному рівні, а також системними змінами обмінних, біохімічних, імунологічних та ендокринних реакцій. За відсутності профілактики, несвоєчасної діагностики й лікування вказаних патологій розвиваються незворотні зміни в зубній системі тварини $[4,7,8]$.

Більшість зарубіжних дослідників розвиток запальних змін у пародонті пояснюють впливом зубної бляшки, що містить велику кількість мікроорганізмів (від 100 до 300 млн. в 1 г зубних нашарувань). Зубна бляшка, просуваючись по мірі росту в підщелепний край, викликає подразнення тканин за рахунок мікроорганізмів i ïx токсинів, що з часом призводить до ураження епітелію ясенної кишені та до запалення прилеглих тканин [3].

Мета роботи - встановити роль мікрофлори порожнини рота у патогенезі запальних захворювань пародонту в котів.

Матеріали і методи. Дослідження проводилися в умовах навчально-науково-виробничої клініки ветеринарної медицини кафедри хірургії та акушерства Полтавської державної аграрної академії та Центральної бактеріологічної лабораторії м. Полтава. Матеріалом дослідження слугували мазки з ротової порожнини та пародонтальних кишень домашніх котів, у яких реєструвалися хвороби пародонту: пародонтит, гінгівіт і зубний камінь. Матеріал відбирали сухим стерильним ватним тампоном у стерильну пробірку й не пізніше двох годин після цього доставляли в лабораторію для подальшого дослідження. Виділення чистих культур проводили з використанням традиційного методу вирощування мікроорганізмів на поверхні щільного поживного

* Керівник-доктор ветеринарних наук Б. П. Киричко 
СТОРІНКА МОЛОДОГО ВЧЕНОГО

\section{1. Частота виділення культур мікроорганізмів та їх концентрація за патологій ротової} порожнини у котів

\begin{tabular}{|c|c|c|c|c|c|c|c|c|c|}
\hline \multirow{2}{*}{ Мікрофлора } & \multicolumn{4}{|c|}{ Гінгівіт, $\mathrm{n}=14$} & \multicolumn{3}{c|}{ Пародонтит, $\mathrm{n}=6$} & \multicolumn{3}{c|}{ Клінічно здорові коти, $\mathrm{n}=4$} \\
\cline { 2 - 10 } & $\begin{array}{c}\text { КУО/мл } \\
(\mathrm{n} \times 105)\end{array}$ & $\%$ & $\begin{array}{c}\text { абсол. } \\
\text { число }\end{array}$ & $\begin{array}{c}\text { КУО/мл } \\
(\mathrm{n} \times 105)\end{array}$ & $\%$ & $\begin{array}{c}\text { абсол. } \\
\text { число }\end{array}$ & $\begin{array}{c}\text { КУО/мл } \\
(\mathrm{n} \times 105)\end{array}$ & $\begin{array}{c}\text { абсол. } \\
\text { число }\end{array}$ \\
\hline Staph. aureus & 0,21 & 75 & $5,25 \pm 0,4$ & 23,0 & 12,5 & $3,3 \pm 0,9$ & 0,4 & 100 & $4 \pm 1,1$ \\
\hline Escherichia coli & - & - & - & 70,0 & 38 & $3,5 \pm 0,5$ & - & - & - \\
\hline Staph. spp. & 0,7 & 25 & $7 \pm 0,05$ & 0,9 & 0,5 & $9 \pm 1,6$ & - & - & - \\
\hline $\begin{array}{c}\text { Enterococcus } \\
\text { faecalis }\end{array}$ & - & - & - & 90,0 & 49 & $4,5 \pm 0,2$ & - & - & - \\
\hline
\end{tabular}

\section{2. Чутливість ізольованих культур бактерій до антибіотиків}

\begin{tabular}{|c|c|}
\hline Вид мікроорганізма & Антибіотики, до яких виявлена чутливість \\
\hline Staph. aureus & $\begin{array}{c}\text { амоксицилін, еритроміцин, роксигексал, лінкоміцин, гентаміцин, } \\
\text { доксицилін, азитроміцин, ципрофлоксацин, оксацилін }\end{array}$ \\
\hline Escherichia coli & гентаміцин, цефтриаксон, амікацин, ципрофлоксацин, цефуроксим \\
\hline Staph. spp. & $\begin{array}{c}\text { амоксицилін, еритроміцин, лінкоміцин, гентаміцин, доксицилін, } \\
\text { ванкоміцин, левофлоксацин }\end{array}$ \\
\hline Enterococcus faecalis & цефтриаксон, еритроміцин, цефтазідім, цефелім, ванкоміцин \\
\hline
\end{tabular}

середовища Мюллера-Хінтона та вивчення ізольованих колоній методом фарбування за Грамом. Чутливість мікроорганізмів до антибіотиків визначали методом дисків [5]. Бактерії вважали чутливими до антибіотиків у разі наявності зони затримки мікробного росту більше ніж 10 міліметрів.

Результати досліджень. Усього досліджено 20 зразків матеріалу від хворих котів, із яких було виділено чотири види мікроорганізмів. Порівнювали кількісний і видовий склад мікрофлори ротової порожнини тварин, хворих на гінгівіт, пародонтит і клінічно здорових тварин. Результати наведені в табл. 1. У котів із гінгівітом ідентифіковано 0,28 КУО, а 3 пародонтитом - 183,9 КУО, у клінічно здорових - 0,4 КУО. Нами відмічено, що у котів з ознаками гінгівіту та зубного каменю переважає кокова мікрофлора; в клінічно здорових вона також виділяється, але в значно меншій кількості. Кокова флора при гінгівітах пред-

\section{БІБЛІОГРАФІЯ}

1. Арсеєнко Д. В. Поширеність хвороб пародонту в собак [Електронний ресурс] - режим доступу: http://vet.okis.ru/ultraparodont.html

2. Васильева М. Б. Воспалительные заболевания пародонта у собак: дисс. ...канд. вет. наук: спец. 16.00 .05 «Ветеринарная хирургия» / М. Б. Васильева. - СПб, 2009. - С. 81-86.

3. Иванов В. С. Заболевания пародонта / В. С. Иванов. - М.: Медицинское информационное агентство, 1998. - С. 47-51.

4. Козій В. I. Порівняльна ефективність різних методів лікування собак із захворюваннями пародон- ставлена стафілококами, до того ж переважає Staph. aureus (75\%). За пародонтиту на тлі зменшення стафілококів (у видовому складі зменшення Staph. aureus - 12,5 \%) зростає кількість ентеробактерій $(87 \%)$. Результати 3 визначення чутливості виділеної мікрофлори до антибіотиків наведені в табл. 2. Таким чином, якщо неможливо визначити чутливість мікрофлори пародонтальних карманів до антибіотиків, можна рекомендувати використання препаратів цефтриаксон та ципрофлоксацин.

Висновки: 1. У мазках із ротової порожнини від котів, хворих на гінгівіт і пародонтит, виділено чотири види мікроорганізмів: Staph. aureus, Escherichia coli, Staph. spp., Enterococcus faecalis.

2. При гінгівітах реєструється кокова мікрофлора, переважно золотистий стафілокок (75 \%), при пародонтитах збільшується частка ентеробактерій (87 \%), відмічається зменшення кількості колоній золотистого стафілокока (12,5%).

ту / Козій В. І., Пацеля І. О. // Вісник Білоцерківського. держ. аграр. ун-ту. - 2009. - № 62. - С. 30-32. 5. Лабинская A. С. Микробиология с техникой микробиологических исследований / А. С. Лабинская. - М.: Медицина, 1978. - 394 с.

6. Мюллер Х.-П. Пародонтология / Х.-П. Мюллер. Львов: ГалДент, 2004 - С. 35-36.

7. Стоматология собак / Фролов В. В., Бейдик О. В., Волков А. А. [и др.] - М.: АквариумПринт, 2006. -209 c.

8. Тимофеев С. В. Стоматология животных / С. В. Тимофеев. - М.: Агровет, 2007. -121 с. 